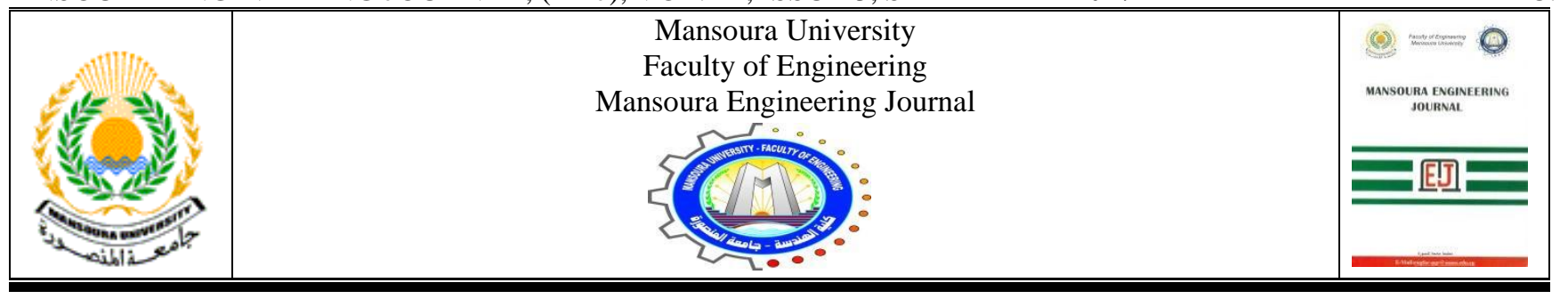

\title{
Removal of Iron and Manganese from Groundwater: A Study of Using Potassium Permanganate and Sedimentation
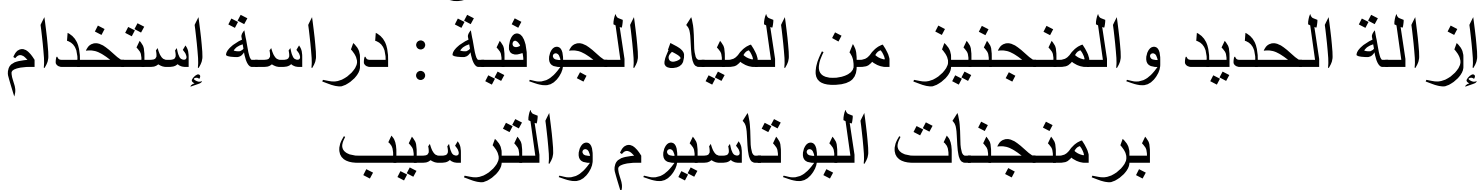

M. A. Elsheikh, H. S. Guirguis and A. Fathy

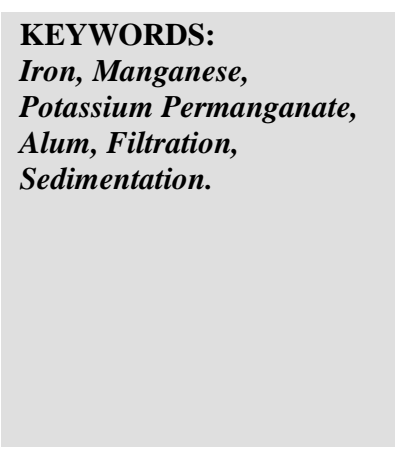

KEYWORDS:

Iron, Manganese,

Potassium Permanganate,

Alum, Filtration,

Sedimentation.

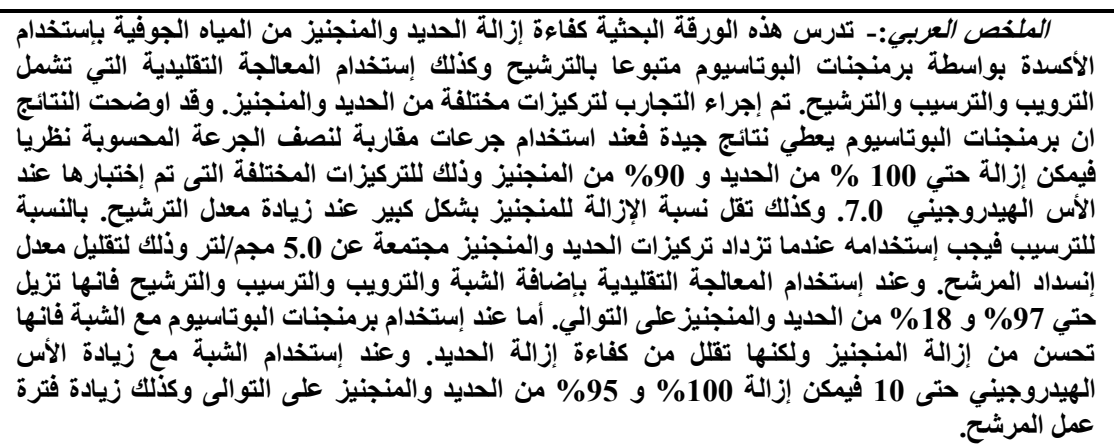

الملفص العربي:- تلرس هذه الورقة البحثية كفاءة إزالة الحليد والمنجنيز من المياه الجوفية بإستخلام

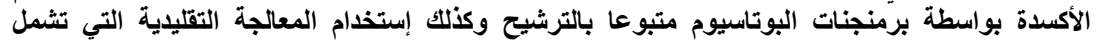

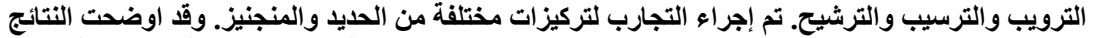

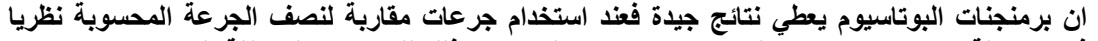

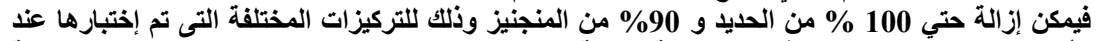

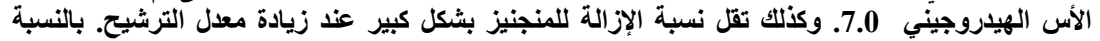

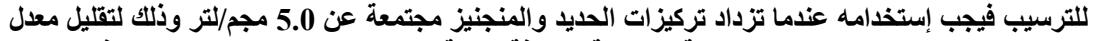

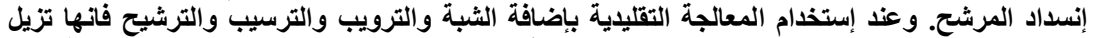

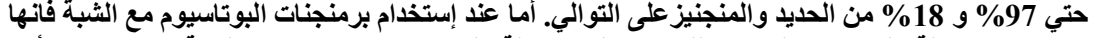

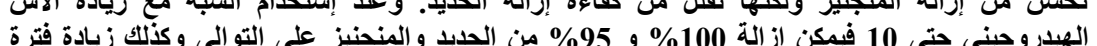
عمل المرشح.

\begin{abstract}
This paper studies the efficiency of iron $\left(\mathrm{Fe}^{+2}\right)$ and manganese $\left(\mathrm{Mn}^{+2}\right)$ removal from groundwater using oxidation by potassium permanganate followed by filtration and using conventional treatment consisting of flocculation, sedimentation and filtration. Experiments were done for different combinations of $\mathrm{Fe}^{+2}$ and $\mathrm{Mn}^{+2}$ concentrations. The obtained results show that Potassium Permanganate (PP) gives good results. By using PP dose equals to half of the theoretically required one, it can remove up to $100 \%$ and $90 \%$ of iron and manganese respectively over different tested concentrations at $\mathbf{p H}=\mathbf{7 . 0}$. Increasing rate of filtration decreases the $\mathrm{Mn}^{+2}$ removal efficiency obviously. Sedimentation is required when combined concentrations of iron
\end{abstract}

Received: 5 June, 2017 - accepted: 1 August, 2017.

M. A. Elsheikh is the head of Civil Engineering Department and Professor of Sanitary and Environmental Engineering at Civil Engineering Department, Menoufia University, Egypt (e-mail: mshafy2@yahoo.com).

H. S. Guirguis is a lecturer of Sanitary and Environmental Engineering at Civil Engineering Department, Menoufia University, Egypt (e-mail: hanyguirguis@yahoo.com).

A. Fathy is a teaching Assistant at Civil Engineering Department, Menoufia University, Egypt (e-mail: engabdo_1990@yahoo.com). and manganese are greater than $5.0 \mathrm{ppm}$ to reduce filter rapid clogging. Using conventional treatment with adding Alum, flocculation, sedimentation and filtration can remove up to $97 \%$ and $18 \%$ of iron and manganese respectively. Using $P P$ in addition to alum enhances manganese removal but decreases iron removal. However, using Alum with raising $\mathrm{pH}$ to 10 leads to $100 \%$ and $95 \%$ of $\mathrm{Fe}^{+2}$ and $\mathrm{Mn}^{+2}$ removal and increases filter working period.

\section{INTRODUCTION}

$\checkmark 1$ ROUNDWATER sources in Egypt can be divided into renewable aquifers like Nile Valley and Delta and non-renewable aquifers like the aquifer of the western desert in the Nubian sandstone [1]. Iron and Manganese are usually present in groundwater as dissolved minerals or associated with other components [2]. Existence of iron and manganese in water causes many problems like water coloring and taste, clothes staining and encouraging bacterial growth in water distribution networks which affect the pipes 


\section{C: 8 M. A. ELSHEIKH, H. S. GUIRGUIS AND A. FATHY}

transfer efficiency [3] but in general they don't cause health problems [4]. The secondary maximum contaminant levels for Iron and Manganese are $0.3 \mathrm{mg} / 1$ and $0.05 \mathrm{mg} / \mathrm{l}$ respectively [5]. The most common methods used to remove iron and manganese include oxidation by Aeration, Chlorine, Chlorine dioxide, Potassium Permanganate and/or Ozone followed by Filtration alone or Sedimentation and Filtration [6,7]. There are other methods that can be used also like using filters with special media like green sand, using Ion exchange, Biological methods or membrane filtration [8].

Potassium Permanganate (PP) is considered a stronger oxidant and has many advantages over other oxidants. Oxidation chemistry of iron and manganese by PP can be described as following [9]:

$$
\begin{aligned}
& 3 \mathrm{Mn}^{+2}+2 \mathrm{KMnO}_{4}+2 \mathrm{H}_{2} \mathrm{O} \longrightarrow 5 \mathrm{MnO}_{4}+2 \mathrm{~K}^{+}+4 \mathrm{H}^{+} \ldots \ldots \ldots \ldots \ldots . . . . . . . \\
& 3 \mathrm{Fe}^{+2}+\mathrm{KMnO}_{4}+7 \mathrm{H}_{2} \mathrm{O} \longrightarrow 3 \mathrm{Fe}(\mathrm{OH})_{3}+\mathrm{K}^{+}+\mathrm{MnO}_{2}+5 \mathrm{H}^{+} \ldots . .(2)
\end{aligned}
$$

To oxidize one $\mathrm{mg}$ of iron and one $\mathrm{mg}$ of manganese, about $0.94 \mathrm{mg}$ and $1.92 \mathrm{mg}$ of PP are required respectively [9].

When iron and manganese exist in high concentrations, they cause filter to run less than 24 hours so a clarification step is needed before filtration to increase the filtration period [10]. Therefore, treatment method would there include flocculation, sedimentation and filtration stages [11].

This paper studies using of PP followed by filtration only or using $\mathrm{PP}$ and/or alum ( $\mathrm{Al}$ ) followed by flocculation, sedimentation and filtration for $\mathrm{Fe}^{+2}$ and $\mathrm{Mn}^{+2}$ oxidation and removal.

\section{Materials AND MethodS}

\section{A. Study Method}

Simulated groundwater was prepared by adding salts of iron and manganese to tap water. The study consists of three stages of experiments: the first one discusses the different factors (e.g. dosages, detention time or $\mathrm{pH}$ ) that affect the oxidation of $\mathrm{Fe}^{+2}$ and $\mathrm{Mn}^{+2}$ by using $\mathrm{PP}$ followed by direct filtration. Experiments were done for $\mathrm{Fe}^{+2}$ and $\mathrm{Mn}^{+2}=1.50$ and $1.0 \mathrm{mg} / \mathrm{l}$ respectively which act the iron and manganese concentration in the Delta region, Egypt. The second stage investigates the results of the first one on other combined concentrations of $\mathrm{Fe}^{+2}$ and $\mathrm{Mn}^{+2}$ by using direct filtration alone also. The third one discusses the efficiency of using sedimentation if high concentrations of $\mathrm{Fe}^{+2}$ and $\mathrm{Mn}^{+2}$ exist. This phase includes flocculation, sedimentation and filtration.

\section{B. The Pilot plant}

Fig. 1 shows the pilot plant which is constructed for the study. It consists of feeding tank, process tank for adding and mixing chemicals, Flocculation and Sedimentation tanks and a Rapid Sand Filter (RSF). For 1st and 2nd phase experiments, the flocculation and sedimentation tanks aren't included. The RSF is made of PVC pipe of internal Diameter $=100 \mathrm{~mm}$ and includes $35 \mathrm{~cm}$ gravel layer with diameter $6: 25 \mathrm{~mm}$ and $75 \mathrm{~cm}$ of coarse sand with Diameter 1.18:1.60 mm. The Rate of Filtration is obtained by controlling the outlet filter valve.

\section{Chemicals}

The Simulated groundwater containing iron and manganese is made by adding ferrous sulfate heptahydrate $\left(\mathrm{FeSO}_{4} \cdot 7 \mathrm{H}_{2} \mathrm{O}\right)$ and manganese sulfate mono-hydrate $\left(\mathrm{MnSO}_{4} \cdot \mathrm{H}_{2} \mathrm{O}\right)$ to tap water. They are obtained from Alnasr company for chemicals, Cairo. Potassium permanganate $\left(\mathrm{KMnO}_{4}\right)$ with $99.90 \%$ purity and aluminum Sulphate Hexadecahydrate $\left.\mathrm{Al} 2\left(\mathrm{So}_{4}\right)_{3} \cdot 16 \mathrm{H}_{2} \mathrm{O}\right)$ were obtained from a Local supplier. Also, Sodium hydroxide $(\mathrm{NaOH})$ was used to adjust $\mathrm{pH}$.

\section{Devices and Analyses}

Iron and manganese measuring devices were used to measure Iron and Manganese concentrations (Hanna, USA). Portable $\mathrm{pH}$ device was used to measure water $\mathrm{pH}$. The devices were calibrated before the study.

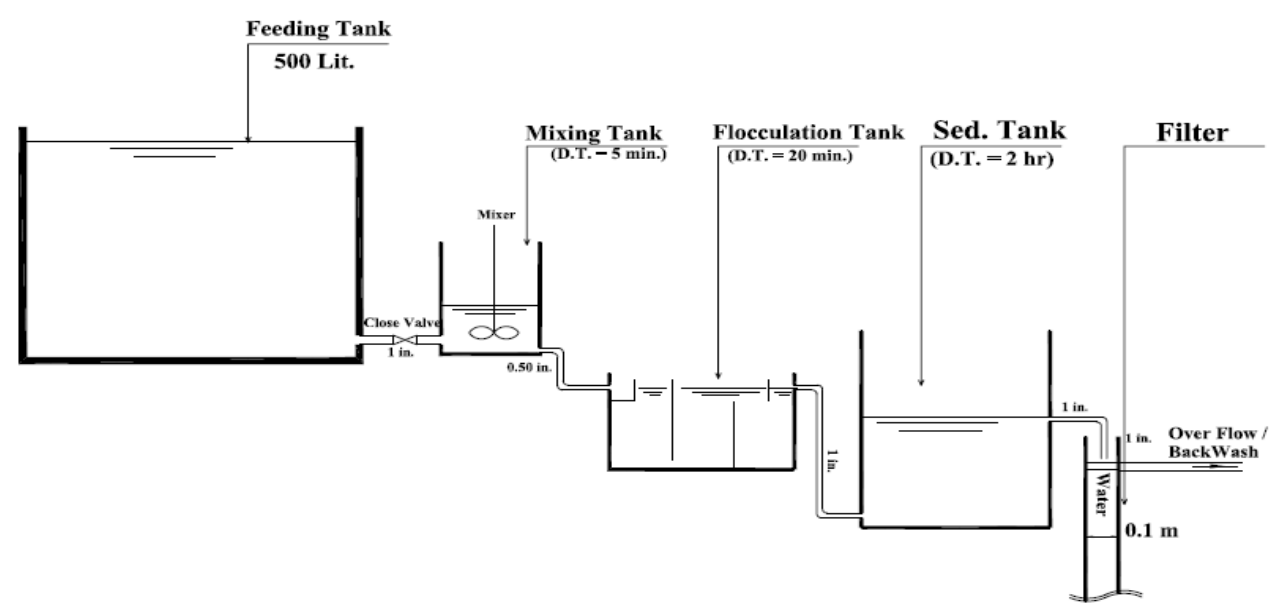

Fig. 1. Pilot Plant with Mixing, Flocculation, Sedimentation and Filtration Tanks. (When direct filtration mode is used, the flocculation and sedimentation tanks are removed.) 


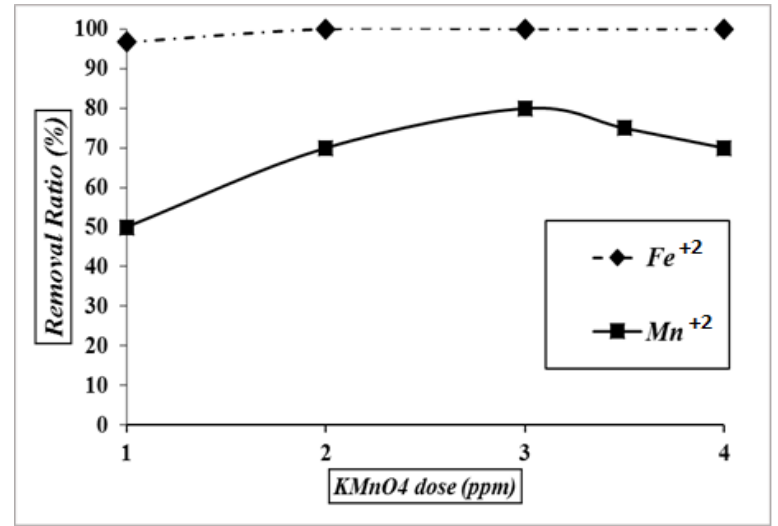

Fig. 2. Effect of using different P.P. doses on $\mathrm{Fe}^{+2}$ and $\mathrm{Mn}^{+2}$ removal (Initial $\mathrm{Fe}^{+2}$ and $\mathrm{Mn}^{+2}$ concentrations are 1.50 and $1.0 \mathrm{mg} / \mathrm{l}$, $\mathrm{pH}=7.0, \mathrm{ROF}=150 \mathrm{~m} / \mathrm{d}$ and $\mathrm{RT}=10 \mathrm{mins})$.

\section{RESULTS AND DISCUSSIONS}

\section{A. Stage 1: Study using Potassium Permanganate}

In this stage, the experiments are done for $\mathrm{Fe}^{+2}$ and $\mathrm{Mn}^{+2}$ concentrations $=1.50$ and $1.0 \mathrm{mg} / \mathrm{l}$ respectively at constant R.O.F. $=150 \mathrm{~m} 3 / \mathrm{m} 2 / \mathrm{d}$. These experiments discuss the removal efficiency of iron and manganese by using potassium permanganate under different conditions like different dosages of PP, retention time, effect of $\mathrm{pH}$ and ROF effect.

\section{1) Effect of PP dosages}

Fig. 2 shows the results of using different PP dosages for $\mathrm{Fe}^{+2}$ and $\mathrm{Mn}^{+2}$ removal. Using a dosage of $1 \mathrm{ppm}$ of PP can remove up to $97 \%$ of iron just after 10 minutes. For Manganese, using PP enhances the removal process greatly at $\mathrm{pH}=7.0$. Using PP dose $=2.0 \mathrm{ppm}$-which is near to half of the theoretically calculated dose- can remove $66 \%$ of Manganese after 10 minutes. Using doses near to the theoretical dose remove up to $80 \%$ of Manganese in just 10 minutes. Increasing PP dosage than the theoretical one has a bad effect on water. When the dosage of $4 \mathrm{ppm}$ is used, the water is colored pink from the effect of increased PP dosage. The increased PP quantity contains Manganese according to the following equation [12]:

$$
\mathrm{KMnO}_{4}+8 \mathrm{H}^{+}+5 e^{-} \rightarrow \mathrm{Mn}^{+2}+\mathrm{K}^{+}+4 \mathrm{H}_{2} \mathrm{O} .
$$

Therefore, a special care should be taken into consideration when choosing the PP dosage. These results agree with other studies that recommend using PP dosages near the theoretical ones [12].

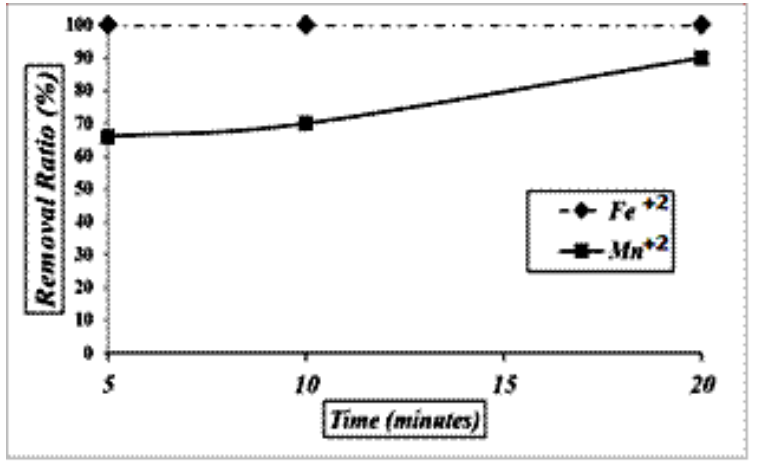

Fig. 3. Effect of Retention time on $\mathrm{Fe}^{+2}$ and $\mathrm{Mn}^{+2}$ removal by P.P. (Initial $\mathrm{Fe}^{+2}$ and $\mathrm{Mn}^{+2}$ conc. are 1.50 and $1.0 \mathrm{mg} / \mathrm{l}, \mathrm{pH}=7.0, \mathrm{PP}=2.0$ $\mathrm{ppm}$ and $\mathrm{ROF}=150 \mathrm{~m} / \mathrm{d}$ )

\section{2) Effect of Retention Time}

The results for using PP dose $=2.0 \mathrm{ppm}$ for R.T. $=5: 20 \mathrm{mins}$ are shown in fig. 3. The oxidation process of iron using PP happens very fast. Complete Iron oxidation needs less than 5 minutes. The oxidation process of Manganese using PP also happens fast and is enhanced by increasing R.T. Using R.T. less than 5 minutes, about $66 \%$ of Manganese is oxidized. Using R.T. equals to 20 minutes increases the R.R. to $90 \%$.

\section{3) Effect of $p H$}

Fig. 4 shows the results of $\mathrm{pH}$ effect on $\mathrm{Fe}^{+2}$ and $\mathrm{Mn}^{+2}$ oxidation by PP dose $=2.0 \mathrm{ppm}$ and R.T. $=10 \mathrm{mins}$ It's shown that Iron is oxidized at $\mathrm{pH}$ greater than 7.0 and much of Manganese oxidation by using PP happens also at $\mathrm{pH}$ near to 7.0. Increasing $\mathrm{pH}$ to 8 and 9 , increases the R.R. to $75 \%$ and $85 \%$ respectively. Therefore, it's concluded that $\mathrm{pH}$ affects the process of $\mathrm{Fe}^{+2}$ and $\mathrm{Mn}^{+2}$ oxidation by PP slightly or by other words, they need $\mathrm{pH}$ greater than 7.0.

The obtained results agree with others which found that the required dose of PP to oxidize $\mathrm{Mn}^{+2}$ was less than that the indicated by the stoichiometry. It is thought that when $\mathrm{Mn}^{+2}$ is separated on the filter, it coats the filter sands and make the filter work as a green sand one, therefore, the required dose becomes smaller [10]. The oxidation time ranges from 5 to 10 minutes, provided that the $\mathrm{pH}$ is over 7.0 [11]. On the other hand, some studies found that the required dosage is slightly more than the required theoretical dose at $\mathrm{pH}$ less than 8.0 [12] and therefore, the required dose should be determined accurately.

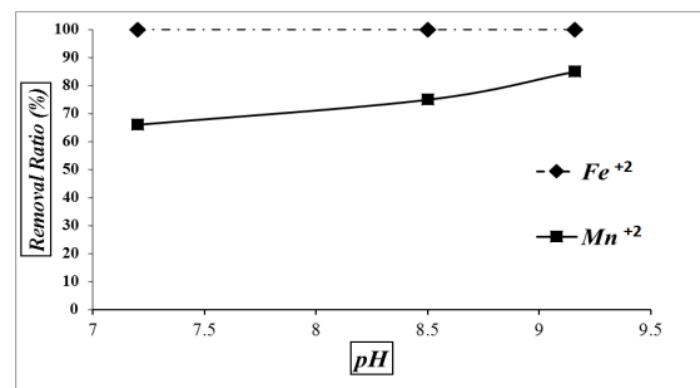

Fig. 4. Effect of $\mathrm{pH}$ on $\mathrm{Fe}^{+2}$ and $\mathrm{Mn}^{+2}$ removal by PP (Initial $\mathrm{Fe}^{+2}$ and $\mathrm{Mn}^{+2}$ conc. are 1.50 and $1.0 \mathrm{mg} / \mathrm{l}, \mathrm{P} . \mathrm{P} .=2.0 \mathrm{ppm}, \mathrm{ROF}=150$ $\mathrm{m} / \mathrm{d}$ and $\mathrm{RT}=10 \mathrm{mins}$ ) 


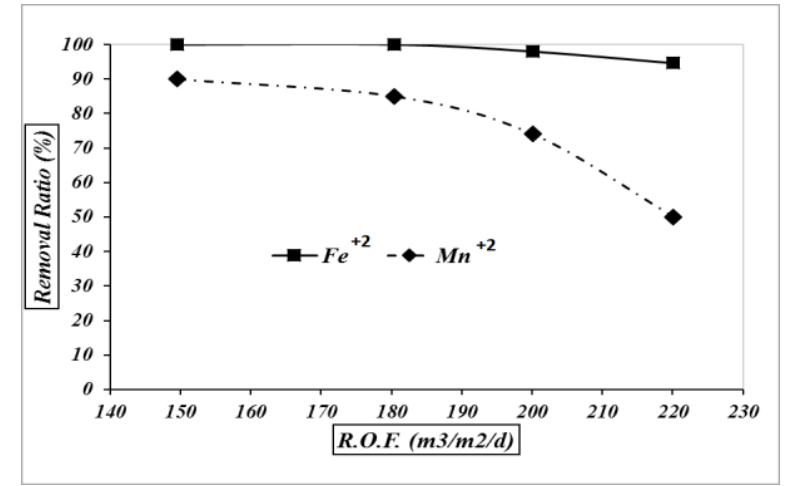

Fig. 5. Effect of R.O.F. on $\mathrm{Fe}^{+2} / \mathrm{Mn}^{+2}$ removal (Initial Fe ${ }^{+2} / \mathrm{Mn}^{+2}$ conc. is $1.50 / 1.0 \mathrm{mg} / \mathrm{l}, \mathrm{pH}=7.0, \mathrm{PP}=2.0 \mathrm{ppm}$ and $\mathrm{RT}=20 \mathrm{~min}$ )

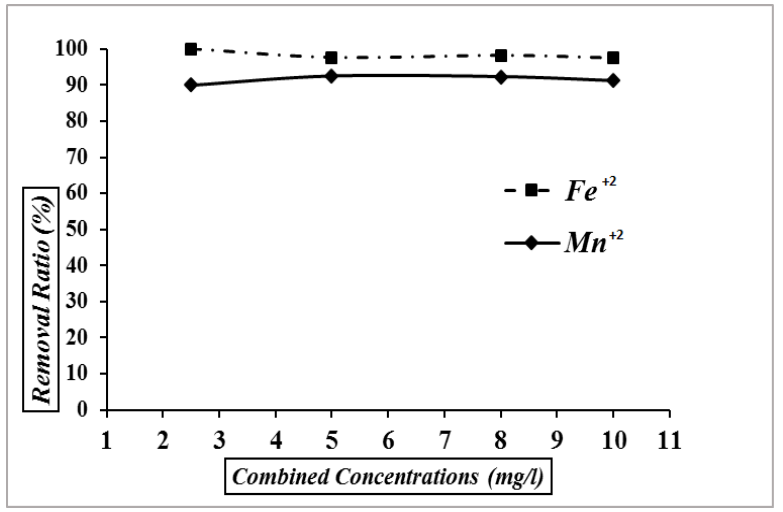

Fig. 6. Effect of using half dose of P.P. on different concentrations of $\mathrm{Fe}^{+2}$ and $\mathrm{Mn}^{+2}$ (Initial $\mathrm{pH}=7.0$, R.T. $=20$ min. Samples are taken and analyzed after 8 hours from filter run start).

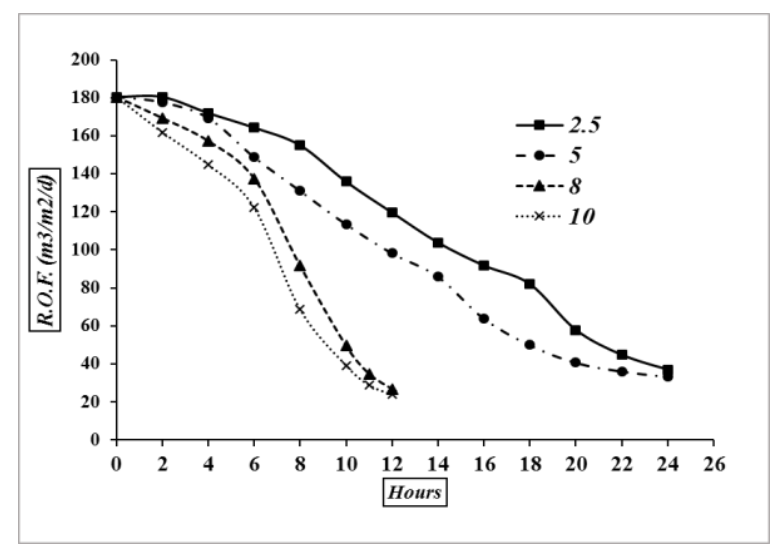

Fig. 7. Change in R.O.F. of different concentrations of $\mathrm{Fe}^{+2}$ and $\mathrm{Mn}^{+2}$ (Initial pH=7.0, R.T.=20 min. All exp. Started at R.O.F. $=180 \mathrm{~m} / \mathrm{d}$ ).

\section{4) Rate Of Filtration (ROF) effect}

The effect of increasing ROF on $\mathrm{Fe}^{+2}$ and $\mathrm{Mn}^{+2}$ removal is shown in fig. 5. PP dose $=2.0 \mathrm{ppm}$ was used for R.T. $=20$ mins. For Iron: increasing ROF from 150 to $180 \mathrm{~m} / \mathrm{d}$ doesn't affect the removal efficiency. At $\mathrm{ROF}=220 \mathrm{~m} / \mathrm{d}$, R.R. becomes $95 \%$. But in general, it's seen that Iron removal is slightly affected by increasing ROF. For Manganese: Biggest R.R. is obtained at ROF equals $150 \mathrm{~m} / \mathrm{d}$. At ROF equals $220 \mathrm{~m} / \mathrm{d}$, the removal ratio becomes $50 \%$ only. Therefore, it's obvious that
TABLE I

$\mathrm{FE}^{+2} / \mathrm{MN}^{+2}$ CONCENTRATIONS OF PHASE 2 EXPERIMENTS

\begin{tabular}{|c|c|c|c|}
\hline $\mathrm{FE}^{+2}(\mathrm{MG} / \mathrm{L})$ & $\mathrm{MN}^{+2}(\mathrm{MG} / \mathrm{L})$ & $\begin{array}{c}\text { COMBINED } \\
\text { CONC. }(\mathrm{MG} / \mathrm{L})\end{array}$ & $\begin{array}{c}\text { P.P. DOSE } \\
(\mathrm{PPM})\end{array}$ \\
\hline 1.5 & 1 & 2.5 & 2 \\
\hline 3 & 2 & 5 & 3.5 \\
\hline 5 & 3 & 8 & 5.5 \\
\hline 6 & 4 & 10 & 7 \\
\hline
\end{tabular}

removal ratio of Manganese depends on ROF in contrast to Iron. Therefore, ROF of $150-180 \mathrm{~m} / \mathrm{d}-(6.25-7.5 \mathrm{~m} / \mathrm{h})-$ is recommended for $\mathrm{Mn}^{+2}$ and $150-220 \mathrm{~m} / \mathrm{d}$ (6.25-9.17) for iron. However, it's reported that recommended $\mathrm{ROF}$ for $\mathrm{Mn}^{+2}$ removal is about $15-18 \mathrm{~m} / \mathrm{hr}$ where for iron is $6-7.5$ which is considered totally different from this study results [11].

\section{E. Stage 2: Study results of Phase 1 on other $\mathrm{Fe}^{+2}$ and $\mathrm{Mn}^{+2}$ concentrations}

In this stage, the experiments were done for different concentrations of Iron and Manganese with using half of the calculated stoichiometric doses of PP. Table I shows these concentrations and the used PP doses. The experiments started with R.O.F. equals to $180 \mathrm{~m}^{3} / \mathrm{m}^{2} / \mathrm{d}, \mathrm{pH}=7.0$ and R.T. equals 20 minutes. The experiments lasted for 24 hours or until ROF became less than $30 \mathrm{~m} / \mathrm{d}$.

\section{1) Effect of using the Half dose of PP}

Fig. 6 shows the results of using Half of PP dose on the removal of $\mathrm{Fe}^{+2}$ and $\mathrm{Mn}^{+2}$ different concentrations. The figure shows that using PP is very efficient to oxidize and remove $\mathrm{Fe}^{+2}$ and $\mathrm{Mn}^{+2}$ at different concentrations. Using half of stoichiometric dose of PP can remove about $98 \%$ of $\mathrm{Fe}^{+2}$ and more than $90 \%$ of $\mathrm{Mn}^{+2}$ despite increasing combined concentrations to $10 \mathrm{mg} / \mathrm{l}$.

\section{2) Filter Clogging Rate}

Fig. 7 shows the change in ROF with time (in hours) for experiments of stage 2 . The change in ROF expresses the velocity of filter clogging at different concentrations. The figure shows that the R.O.F. is decreased with time. This occurs as removed iron and manganese accumulate on filter media and start to clog the filter. It's shown that increasing $\mathrm{Fe}^{+2}$ and $\mathrm{Mn}^{+2}$ Concentrations lead to rapid filter clogging. when concentrations of iron and manganese exceed $5.0 \mathrm{mg} / \mathrm{l}$, the removed particles cause rapid clogging of filters and decrease the period of filter run to be less than 12 hours. This period isn't practical nor economical to be applied to water treatment plants as the ratio of backwash water will increase. Therefore, it's recommended that when the combined concentrations exceed $5.0 \mathrm{mg} / \mathrm{l}$ to use sedimentation before filtration. other studies suggest using sedimentation when combined concentrations of $\mathrm{Fe}^{+2}$ and $\mathrm{Mn}^{+2}$ exceed $8.0 \mathrm{mg} / 1$ [8] or when iron concentration is greater than $5.0 \mathrm{mg} / 1$ [11]. 
F. Stage 3: Study using Conventional treatment to remove $\mathrm{Fe}^{+2}$ and $\mathrm{Mn}^{+2}$ :

This set of experiments deals with using Conventional treatment to remove $\mathrm{Fe}^{+2}$ and $\mathrm{Mn}^{+2}$ when they are found in high concentrations.

The treatment includes adding alum (with/without other chemicals), mixing with water for 5 mins, flocculation for 25 mins, sedimentation for $2.0 \mathrm{hrs}$ and then filtration. This set discusses using alum alone, Alum with PP and Alum with increasing $\mathrm{pH}$ followed by filtration and sedimentation.

Fig. 8 shows the results obtained from these experiments. It is shown that using alum alone can remove high ratio of $\mathrm{Fe}^{+2}$. By using alum dose $=60 \mathrm{ppm}$, about $97 \%$ of $\mathrm{Fe}^{+2}$ can be removed. However, the R.R. of $\mathrm{Mn}^{+2}$ doesn't exceed $18 \%$. Using PP with Alum enhanced $\mathrm{Mn}^{+2}$ R.R. to reach about $63 \%$ but decreased $\mathrm{Fe}^{+2}$ R.R. to $79 \%$ when PP dose=5.0 ppm used with Alum dose $=40 \mathrm{ppm}$. Using alum alone with increasing water $\mathrm{pH}$ to over 10 leads to complete removal of Iron and about $95 \%$ of $\mathrm{Mn}^{+2}$.

Another study found that $\mathrm{Fe}^{+2} / \mathrm{Mn}^{+2}$ removal ratios by Coagulation and Clarification were about $18: 75 \%$ and $8: 24 \%$ for $\mathrm{Fe}^{+2} / \mathrm{Mn}^{+2}$ respectively for different concentrations of iron and manganese. However, when PP was used, $\mathrm{Fe}^{+2}$ R.R. was about $99 \%$ which is greater than our study results and $\mathrm{Mn}^{+2}$ R.R. was $72 \%$ which is similar to the above results [13].

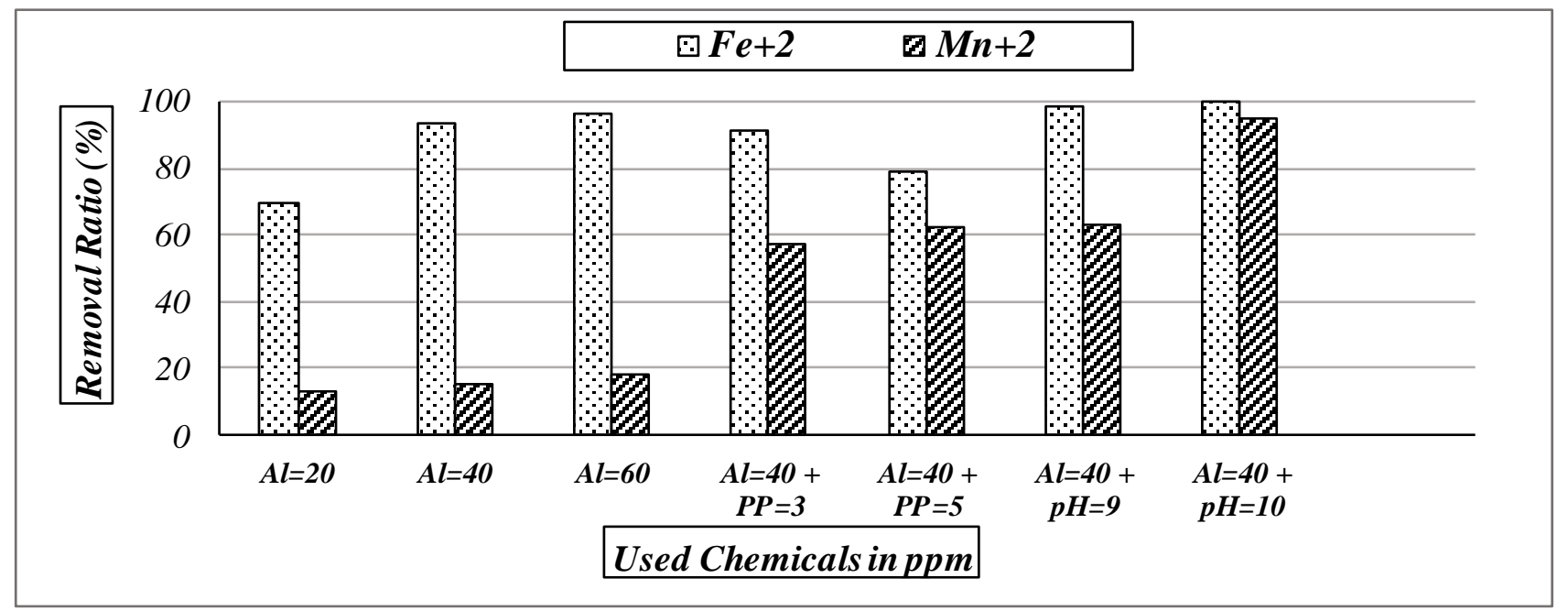

Fig. 8. Results of using conventional treatment for removal of $\mathrm{Fe}^{+2}=5.0 \mathrm{mg} / \mathrm{l}$ and $\mathrm{Mn}^{+2}=3.0 \mathrm{mg} / \mathrm{l}$ (Initial $\mathrm{pH}=7.0$, All exp. Started at ROF=150 m/d and samples are taken after 10 hours from filtration start).

\section{G. Recommendations}

\section{1) Using $P P$}

$\mathrm{PP}$ is considered a good selection for the process of iron and manganese removal. The experiments show that using dosages near to half of the required theoretical dose at $\mathrm{pH}=7.0$ and retention time of 20 minutes can remove iron completely and $90 \%$ of manganese. However, the applied dose should be determined very accurately to prevent water coloring.

\section{2) Using sedimentation}

Sedimentation is required when iron and manganese combined concentrations exceed $5.0 \mathrm{mg} / \mathrm{l}$ to allow longer filtration periods.

\section{3) Using Alum}

Using alum with sedimentation alone can't remove high ratio of manganese. However, using alum with raising $\mathrm{pH}$ to 10 leads to remove high ratio of both $\mathrm{Fe}^{+2} / \mathrm{Mn}^{+2}$ concentrations.

\section{REFERENCES}

[1] R. Ahmed, E. Saafb and Mohamed A. Dawoud, "Desalination of brackish groundwater in Egypt," Desalination, vol. 152, pp. 19-26, 2002.

[2] C. Qingfeng, N. Lichao and B. Linlin, "Interactions between ammonia, iron and manganese removal using pilot-scale biofilters" Journal of Water Supply: Research and Technology, AQUA, in press, 2017.

[3] D. N. Manav, "Experimental Study of Factors that Affect Iron and Manganese Removal in Slow Sand Filters and Identification of Responsible Microbial Species," Polish Journal of Environmental Studies, vol. 25.4, pp. 1453-1465, 2016.

[4] M. Azrin, Mohd N., and Mohd R., "Removal of Iron and Manganese Using Cascade Aerator and Limestone Roughing Filter," Materials Science Forum, Vol. 857, pp. 509-513, 2016.

[5] R. El Araby, S. Hawash and G. El Diwani, "Treatment of Iron and Manganese in simulated groundwater via ozone technology," Desalination, Vol. 249, pp. 1345-1349, 2009.

[6] C. Wen-Hsiang, Yung-Hsu H. and Chih-Chao W., "The on-site feasibility study of Iron and Manganese removal from groundwater by hollow-fiber microfiltration," Journal of Water Supply: Research and Technology-AQUA, pp. 391-401, 2011.

[7] K. Jutta, Jarmo T., "Mn(II) removal from groundwater with Manganese oxide coated filter media," Journal of Environmental Science and 


\section{C: 12 M. A. ELSHEIKH, H. S. GUIRGUIS AND A. FATHY}

Health, Part A: Toxic/Hazardous Substances and Environmental Engineering, Vol. 45:13, pp. 1732-1740, 2010.

[8] C. John, Mark T.: "Iron and manganese removal handbook", American Water Works Association, 2nd edition, 2015.

[9] P. Piaw, Jatuporn W. and Wen-Hsiang C., "Removal of Manganese(II) and Iron(II) from synthetic groundwater using potassium permanganate," Desalination and Water Treatment, vol. 52, pp. 5942 5951, 2014.

[10] H. Lee Odell: “Treatment technologies for Groundwater", American Water Works Association, 1st edition, 2010.

[11] K. M. Johnson, D. D. Ratnayaka and M. J. Brandt: “Twort's Water Supply," Elsevier Ltd CO., 7th edition, 2016.
[12] G. Khadse, P. Patnil and P. Labhasetwar, 'Removal of iron and manganese from drinking water supply,' Sustain. Water Resources Management, Vol. 1, pp. 157-165, 2015.

[13] D. Zogo, Bawa L., Soclo H. and Atchekpe D., "Influence of preoxidation with potassium permanganate on the efficiency of iron and manganese removal from surface water by coagulation-flocculation using aluminium sulphate: Case of the Okpara dam in the Republic of Benin," Journal of Environmental Chemistry and Ecotoxicology, Vol. 3(1), pp. 1-8, January 2011. 